\title{
Phytosociological Survey of Weeds in Carpet Grass in Distinct PERIODS OF THE YEAR ${ }^{1}$
}

\author{
Levantamento Fitossociológico de Plantas Daninhas em Grama-Sempre-Verde em Diferentes \\ Épocas do Ano
}

\author{
MACIEL, C.D.G. ${ }^{2}$, OLIVEIRA, C.N.M. ${ }^{2}$, SILVA, A.A.P. ${ }^{2}$, KARPINSKI, R.A.K. ${ }^{2}$, HELVIG, E.O. ${ }^{2}$, and \\ MATIAS, J.P. ${ }^{3}$
}

\begin{abstract}
Lawn with grass classified as Axonopus compressus is very common in Brazil Southern region, where it normally presents an adequate low temperature tolerance and a high diversity of weed infestation. This work has aimed to conduct a phytosociological survey of weeds in lawn consisting of Axonopus compressus from CEDETEG/UNICENTRO University campus located in the Brazilian municipality of Guarapuava, in the state of Paraná, in different periods of 2013. One hundred eighty $0.50 \times 0.50 \mathrm{~m}$ samples were collected in four months, from which parameters frequency, density, abundance, relative frequency, relative density, relative abundance and importance value index were calculated. In general, 24, 7, 17 and 14 weed species were identified, distributed in 23, 3, 8 and 6 families, respectively, in April, June, October and December. The largest number of weed species was identified in Asteraceae, Fabaceae and Cyperaceae families. The ones classified as the most important and with occurrence over all periods of year were Trifolium repens (Fabaceae), Soliva pterosperma (Asteraceae) and Oxalis corniculata (Oxalidaceae).
\end{abstract}

Keywords: Axonopus compressus, lawn, identification.

RESUMO - Gramados com a grama denominada sempre-verde (Axonopus compressus) são muito comuns na região Sul do Brasil, onde normalmente apresentam boa tolerância ao frio e alta diversidade de infestação de plantas daninhas. Este trabalho teve como objetivo a realização de um levantamento fitossociológico de plantas daninhas em gramado composto por grama-sempre-verde do campus universitário CEDETEG/UNICENTRO, localizado em Guarapuava-PR, em diferentes épocas do ano de 2013. Cento e oitenta amostras de 0,5 × 0,5 m foram coletadas em quatro meses, a partir das quais foram calculados os parâmetros frequência, densidade, abundância, frequência relativa, densidade relativa, abundância relativa e indice de valor de importância. De modo geral, foram identificadas 24, 7, 17 e 14 espécies de plantas daninhas, distribuídas em 23, 3, 8 e 6 famílias, respectivamente, nos meses de abril, junho, outubro e dezembro. O maior número de espécies de plantas daninhas foi identificado para as famílias Asteraceae, Fabaceae e Cyperaceae; aquelas que as classificadas como as mais importantes e com ocorrência em todas as épocas do ano foram Trifolium repens (Fabaceae), Soliva pterosperma (Asteraceae) e Oxalis corniculata (Oxalidaceae).

Palavras-chave: Axonopus compressus, gramado, identificação.

\section{INTRODUCTION}

Carpet grass or curitibana (Axonopus compressus is widely used to form lawn in gardens, parks, residential areas, public squares, among others, in Southern Brazil
(Lorenzi and Souza, 2001; Busey, 2003). Species A. compressus has good tolerance to colder weather and little resistance to drought. Its origin is reported in South America, and it may be a native in southern Brazil (Lorenzi and Souza, 2001; Kojoroski-Silva et al., 2011).

1 Recebido para publicação em 4.2.2016 e aprovado em 9.6.2016.

2 Universidade Estadual do Centro-Oeste, PPGA/UNICENTRO. Guarapuava, PR, Brasil, <cmaciel@unicentro.br $>$; ${ }^{3}$ Universidade Estadual de Maringá, PAG/UEM, Campus Regeional. Umuarama, PR, Brasil. 
In agriculture, when a plant is in unwanted place and time it is considered invasive and/ or a weed, as it negatively interferes in activities of economic interest. According to Vermeij (1996), invasive species, when introduced from other environments, adapt and begin to reproduce enough to occupy the space of native species and produce changes in natural ecological processes, tending to become dominant after a period of time required to adapt. Thus, weeds can, besides competing for water, light and nutrients, impair the physical space, formation, aesthetics and management of lawn, ending up, in some cases, to decimating it altogether (Freitas et al., 2003).

The use of poor quality soil and seedlings is usually one of the factors that most influence the introduction of weeds in lawn. Therefore, it is important to know the weed community, as well as the investment in efficient methods to assist in this practice, since, with this, the type of management to be adopted is going to be directed, as well as how and when to use it (Deuber, 1997).

Maciel et al. (2008) have reported the absence in the literature of information on the frequency of the weed community prevalent in lawn in the different regions of Brazil, as well as the shortage of technical information for its implementation and maintenance. Silva et al. (2008) have mentioned the need to recognize the weed species so that likely eradication procedures are more effectively implemented, since its control may depend on the particular characteristics of each species.

The methodology used in floristic recognition or not of agricultural areas is the phytosociological study, which involves species interrelations in certain location and time. According to Concenço et al. (2013), the phytosociological survey is defined by a group of ecological assessment methods in order to provide a comprehensive view of both the composition and the distribution of plant species in a certain community. To be valid, one must choose the most suitable and ecologically based methods, since cultured environments have a relatively distinct group of selection factors compared to natural environments.

Planta Daninha, Viçosa-MG, v. 34, n. 4, p. 691-700, 2016
Thus, this study has aimed to carry out a phytosociological survey of weeds in lawn of carpet grass (A. compressus) at CEDETEG/ UNICENTRO campus, in the Brazilian municipality of Guarapuava, PR, in different times of the year.

\section{MATERIALS AND METHODS}

The phytosociological survey of the weed community was made by sampling with identification and quantification of weeds in lawn of carpet grass (A. compressus), located at municipality of Guarapuava, PR, Brazil, during April, July, October and December 2013. The soil in the area where the survey was conducted is classified as typical dystrophic bruno latosol (Embrapa, 2013) and the Köppen climate classification is humid mesothermal subtropical Cfb (Köppen, 1948), with cool summers and winters with the occurrence of severe and frequent frosts, showing no dry season. In Figure 1, it is possible to see the climatological data regarding the period for the execution of the work.

Repetitions were represented by sampling performed with the aid of a hollow frame with an internal area of $0.25 \mathrm{~m}^{2}$, totaling a final area of $45 \mathrm{~m}^{2}$ in the evaluations of the four months, similarly to the methodologies described by Maciel et al. (2008).

In the classification of the species, the Angiosperm Phylogeny Group II (2003) system was taken as a basis to aid in the delimitations of families and organizing some genera, according to Souza and Lorenzi (2005). However, in the identification and quantification of species, specific literature (Kissman and Groth, 1997, 1999, 2000; Lorenzi and Souza, 2001; Lorenzi, 2008) was also used, besides the assistance of bibliographies on medicinal and ornamentals plants, and dissertations and theses related to the subject.

Depending on the data obtained, phytosociological parameters were determined: number of individuals per species; number of plots where the species is present; frequency (occurrence index of species in each frame); density (ratio of the number of individuals of the same species in each frame); relative abundance (concentration of species in 


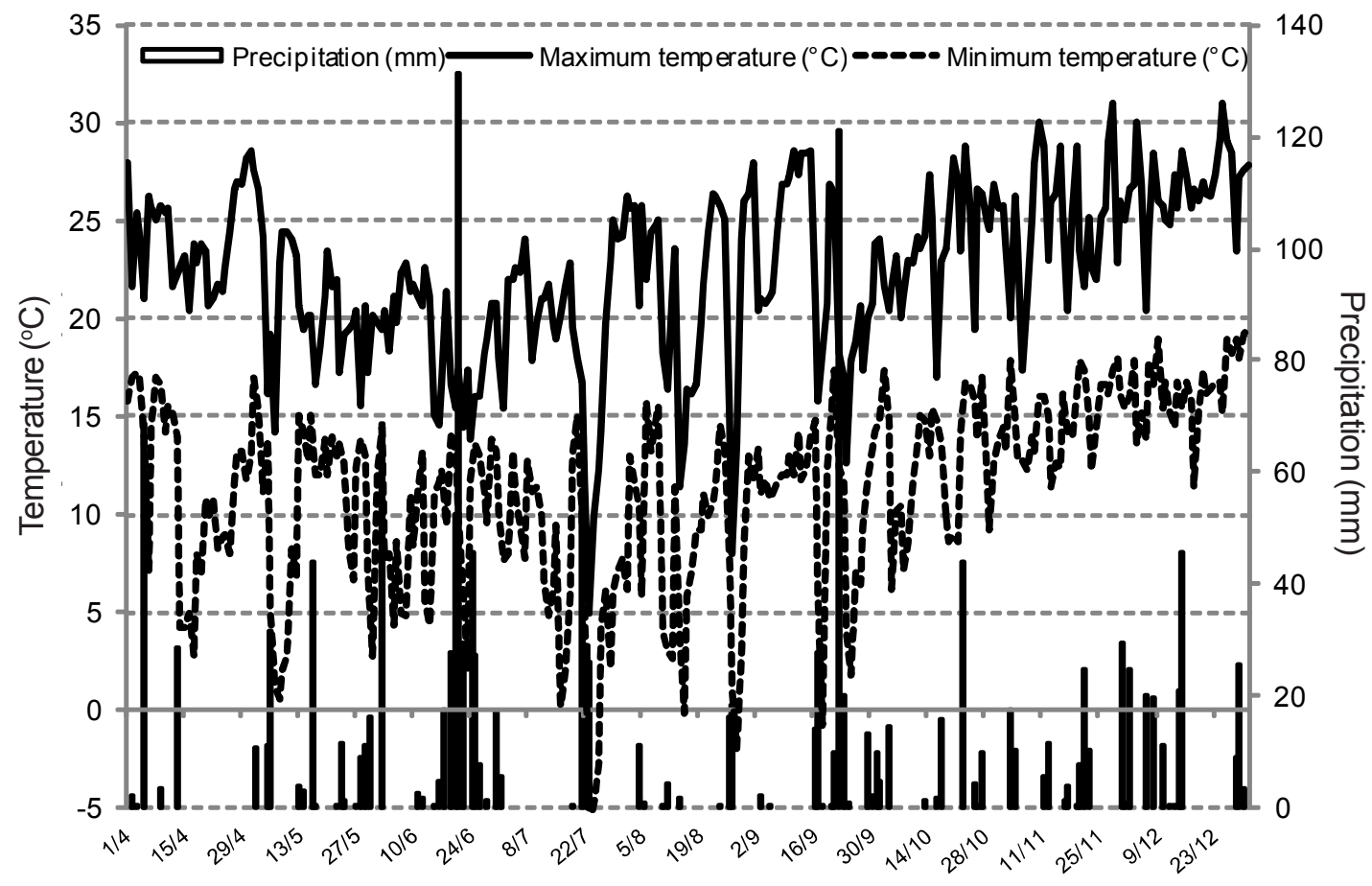

Figure 1 - Meteorological data regarding the survey period of weeds in carpet grass. Guarapuava, PR, 2013.

different parts of the total area $-\mathrm{m}^{2}$ ); and the Importance Value Index (IVI), according to Müeller-Dombois and Ellenberg (1974).

In the calculation of the parameters used, the following formulas were used:

- Frequency $($ Fre $)=$ [number of plots containing the species/total number of plots used]

- Density $($ Den $)=[$ total number of individuals per species/total area collected]

- Abundance $(\mathrm{Abu})=$ [total number of individuals per species/total number of plots containing the species]

- Relative frequency $(F r r)=$ [frequency of the species $\times 100 /$ total frequency of the species]

- Relative density (Der) $=$ [density of the species $\mathrm{x} 100 /$ total density of the species]

- Relative abundance (Abr) = [abundance of the species $\times 100 /$ total abundance of the species]

- Importance Value Index (IVI) $=[$ Frr + Der + Abr]

In addition, the floristic similarity between the botanical populations of the four seasons was determined using the
Sørensen-Dice Similarity Index (SI\%), $\mathrm{SI}=(2 \mathrm{a} / \mathrm{b}+\mathrm{c}) \times 100$, where $\mathrm{a}=$ number of species common to both areas; and $b$ and $\mathrm{c}=$ total number of species in both areas compared. The SI constitutes a range from 0 to $100 \%$, being maximal when all species are common to both areas and minimal when there are no common species (Oliveira and Freitas, 2008).

\section{RESULTS AND DISCUSSION}

The floristic survey of weeds in lawn of carpet grass (A. compressus) at CEDETEG/ UNICENTRO campus totaled 1,084, 1,491, 2,982 and 1,271 plants, located at 180 sampling points in April, July, October and December 2013, respectively (Tables 1 to 4). Overall in the four surveys, 24, 7, 17 and 14 species of weeds were identified, distributed in $12,3,8$ and 6 families, respectively, present in April, June, October and December 2013 (Figure 2).

The families with the highest number of weed species in all periods assessed were Asteraceae, Fabaceae and Cyperaceae (Figure 2). According to Grombone-Guarantini and Rodrigues (2002), the fact that the vast 


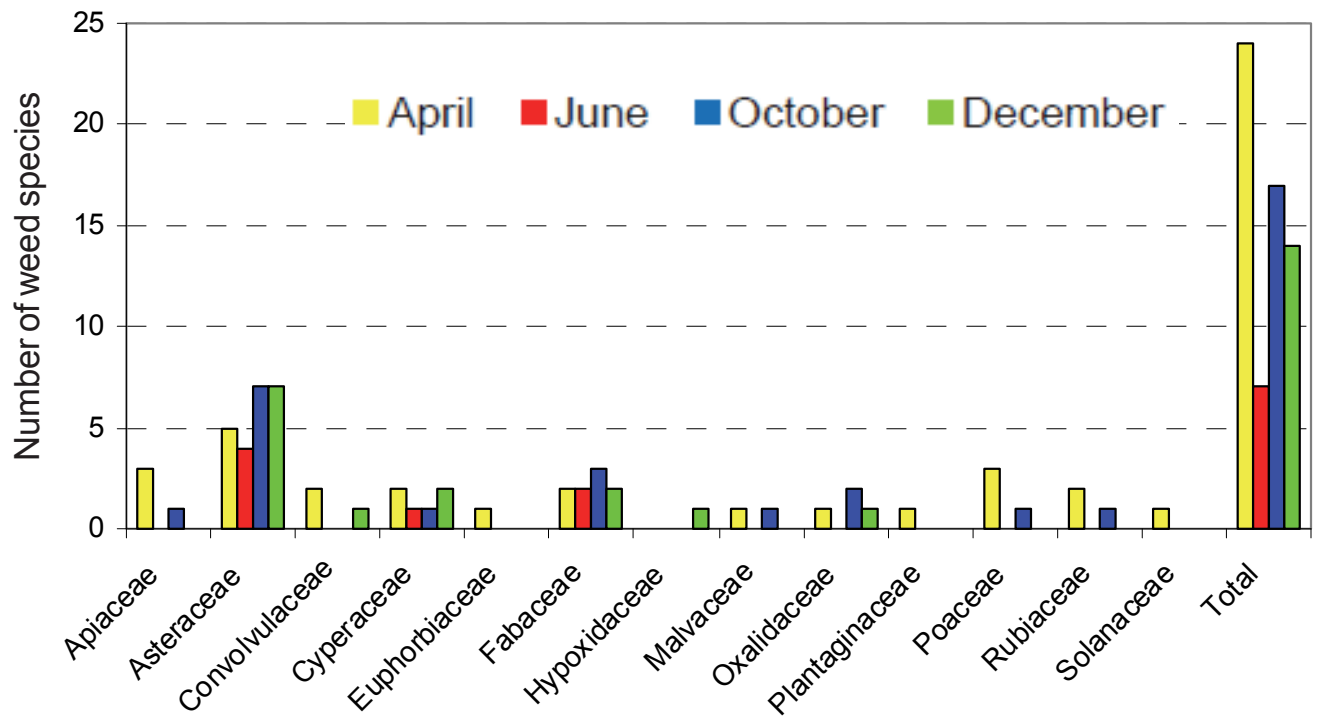

Figure 2 - Number of weed species belonging to their families in April, June, October and December 2013, identified in lawn of carpet grass (A. compressus) at CEDETEG/UNICENTRO campus. Guarapuava, PR, 2013.

majority of Asteraceae species present rapid spread by the wind (anemophilous dispersion) makes it a generalist, favoring the growth in open areas. For Kissmann and Groth (1999), the dissemination strategy of propagules of Asteraceae species favors mainly by their characteristic of aggressive colonization and inhibiting the growth of other plants.

Other phytosociological surveys of weeds conducted in different climatic and soil conditions in Brazil have also shown families Asteraceae, Fabaceae and Cyperaceae among those identified with the most prevalent species in lawn of Paspalum notatum (Maciel et al., 2008; Nordi and Landgraf, 2009; Maciel et al., 2010a; Oliveira, 2011) and of Zoysia japonica (Maciel et al., 2010b).

Maciel et al. (2010b), through a phytosociological survey of residential gardens with dwarf eelgrass or Japanese eelgrass (Z. japonica) in the Brazilian municipality of Ourinhos, SP, have also found a decrease in the number of species identified between March and October, indicating that several factors may be involved in this result. According to these authors, among the main aspects, climate change and maintenance of the mowing and/or management in lawn it highlighted, which can interfere with the emergence and establishment of weeds. Thus, it is important to note that June and April were the months with the lowest and highest incidences of weed families and species, respectively. This may be explained by the higher temperatures in April, October and December compared to June, having conditioned the best adaptation of invasive species in the seed bank of the area (Figure 1).

In descending order, the four species that showed the highest relative frequencies in April were: Soliva pterosperma (Asteraceae), Trifolium repens (Fabaceae), Bulbostlylis capilaris (Cyperaceae) and Oxalis corniculata (Oxalidaceae), represented by levels of $66.5 \%$, $56.1 \%, 33.0 \%$ and $24.0 \%$, respectively (Table 1 ). Among them, in relation to the density and abundance, S. pterosperma and T. repens stood out.

In June, species $T$. repens showed the highest frequency, density and relative abundance, followed by Hypochoeris brasiliensis (Asteraceae) (Table 2). In October, the four species that showed the highest relative frequencies were: S. pterosperma and Sida rhombifolia (Malvaceae), Taraxacum officinale (Asteraceae) and $H$. brasiliensis, represented, respectively, by $14.3 \%, 12.6 \%, 12.1 \%$ and $9.4 \%$ (Table 3). Similarly to April, regarding the density, species $T$. repens and $S$. pterosperma (55.6 and 45.9 plants $\mathrm{m}^{-2}$ ) again stood out in October, belonging to families Fabaceae and Asteraceae, respectively. According to 
Phytosociological survey of weeds in carpet grass in ...

Table 1 - Phytosociological parameters of weeds identified in carpet grass (A. compressus) at CEDETEG/UNICENTRO campus during April 2013. Guarapuava, PR, 2013

\begin{tabular}{|c|c|c|c|c|c|c|c|c|c|c|}
\hline Species & Common name & $\begin{array}{l}\text { No. of } \\
\text { frames }\end{array}$ & \begin{tabular}{|c|} 
No. of \\
individuals
\end{tabular} & Fre & Den & $\mathrm{Abu}$ & Frr & Der & Abr & IVI \\
\hline Andropogon bicornis & $\begin{array}{l}\text { beard grass, bluestem } \\
\text { grass, or broomsedge }\end{array}$ & 1 & 1 & 0.07 & 0.3 & 1.0 & 1.75 & 0.09 & 0.40 & 2.24 \\
\hline Desmodium adscendens & $\begin{array}{c}\text { In Brazilian Portuguese, } \\
\text { pega-pega }\end{array}$ & 1 & 17 & 0.07 & 4.5 & 17.0 & 1.75 & 1.57 & 6.73 & 10.06 \\
\hline Nicandra physaloides & $\begin{array}{l}\text { apple-of-Peru or shoo-fly } \\
\text { plant }\end{array}$ & 2 & 2 & 0.13 & 0.5 & 1.0 & 3.51 & 0.18 & 0.40 & 4.09 \\
\hline Baccharis trimera & $\begin{array}{c}\text { In Brazilian Portuguese, } \\
\text { cacália }\end{array}$ & 1 & 15 & 0.07 & 4.0 & 15.0 & 1.75 & 1.38 & 5.94 & 9.08 \\
\hline Eryngium horridum & $\begin{array}{c}\text { In Brazilian Portuguese, } \\
\text { gravatá }\end{array}$ & 1 & 1 & 0.07 & 0.3 & 1.0 & 1.75 & 0.09 & 0.40 & 2.24 \\
\hline Dichondra repens & $\begin{array}{c}\text { In Brazilian Portuguese, } \\
\text { dinheiro-em-penca }\end{array}$ & 3 & 31 & 0.20 & 8.3 & 10.3 & 5.26 & 2.86 & 4.09 & 12.22 \\
\hline Merremia aegyptia & $\begin{array}{c}\begin{array}{c}\text { In Brazilian Portuguese, } \\
\text { jetirana }\end{array} \\
\end{array}$ & 1 & 7 & 0.07 & 1.8 & 7.0 & 1.75 & 0.65 & 2.77 & 5.17 \\
\hline Trifolium repens & $\begin{array}{c}\text { white clover, Dutch } \\
\text { clover, or Ladino (clover) }\end{array}$ & 8 & 297 & 0.53 & 79.2 & 37.1 & 14.04 & 27.40 & 14.71 & 56.14 \\
\hline Bulbostylis capillaris & $\begin{array}{c}\text { densetuft hairsedge or } \\
\text { threadleaf beakseed }\end{array}$ & 6 & 142 & 0.40 & 37.8 & 23.6 & 10.53 & 13.10 & 9.38 & 33.00 \\
\hline Oxalis corniculata & $\begin{array}{c}\text { creeping woodsorrel, } \\
\text { procumbent yellow- } \\
\text { sorrel, or sleeping beauty }\end{array}$ & 5 & 89 & 0.33 & 23.7 & 17.8 & 8.77 & 8.21 & 7.05 & 24.03 \\
\hline Gnaphalium spicatum & cudweeds & 1 & 32 & 0.07 & 8.5 & 32.0 & 1.75 & 2.95 & 12.68 & 17.38 \\
\hline Apium leptophyllum & $\begin{array}{c}\text { marsh parsley, slender } \\
\text { celery, or fir-leaved } \\
\text { celery }\end{array}$ & 1 & 14 & 0.07 & 3.7 & 14.0 & 1.75 & 1.29 & 5.55 & 8.59 \\
\hline Chamaesyce hirta & asthma-plant & 1 & 1 & 0.07 & 0.3 & 1.0 & 1.75 & 0.09 & 0.40 & 2.24 \\
\hline Soliva pterosperma & $\begin{array}{c}\text { field burrweed, } \\
\begin{array}{c}\text { Onehunga-weed, lawn } \\
\text { burrweed, lawnweed, } \\
\text { soliva, bindi weed, bindii, } \\
\text { or bindi-eye }\end{array} \\
\end{array}$ & 9 & 372 & 0.60 & 99.2 & 41.3 & 15.79 & 34.32 & 16.37 & 66.48 \\
\hline Sida glaziovii & fanpetals or sidas & 2 & 13 & 0.13 & 3.5 & 6.5 & 3.51 & 1.20 & 2.58 & 7.28 \\
\hline Pantago tomentosa & plantains or fleaworts & 1 & 1 & 0.07 & 0.3 & 1.0 & 1.75 & 0.09 & 0.40 & 2.24 \\
\hline Setaria geniculata & $\begin{array}{c}\text { marsh bristlegrass, } \\
\text { knotroot bristle-grass, } \\
\text { bristly foxtail, or yellow } \\
\text { bristlegrass }\end{array}$ & 2 & 2 & 0.13 & 0.5 & 1.0 & 3.51 & 0.18 & 0.40 & 4.09 \\
\hline Centella asiatica & $\begin{array}{l}\text { centella, gotu kola, } \\
\text { Asiatic pennywort, or } \\
\text { Indian pennywort }\end{array}$ & 2 & 36 & 0.13 & 9.6 & 18.0 & 3.51 & 3.32 & 7.13 & 13.96 \\
\hline Richardia brasiliensis & $\begin{array}{c}\text { Tropical Mexican clover, } \\
\text { Brazilian calla-lily, } \\
\text { white-eye, or Brazil } \\
\text { pusley }\end{array}$ & 1 & 1 & 0.07 & 0.3 & 1.0 & 1.75 & 0.09 & 0.40 & 2.24 \\
\hline Diodella teres & $\begin{array}{c}\text { Tropical fanpetals, balai- } \\
\text { zortie }\end{array}$ & 1 & 1 & 0.07 & 0.3 & 1.0 & 1.75 & 0.09 & 0.40 & 2.24 \\
\hline Synedrellopsis grisebachii & Straggler daisy & 1 & 1 & 0.07 & 0.3 & 1.0 & 1.75 & 0.09 & 0.40 & 2.24 \\
\hline Kyllinga brevifolia & $\begin{array}{l}\text { shortleaf spikesedge, } \\
\text { green kyllinga, or } \\
\text { perennial greenhead } \\
\text { sedge }\end{array}$ & 3 & 5 & 0.20 & 1.3 & 1.67 & 5.26 & 0.46 & 0.66 & 6.38 \\
\hline Hydrocotile bonariensis & Coast pennywort & 1 & 1 & 0.07 & 0.3 & 1.0 & 1.75 & 0.09 & 0.40 & 2.24 \\
\hline Eragrotis pilosa & $\begin{array}{c}\text { Indian lovegrass, Jersey } \\
\text { love-grass, hairy love } \\
\text { grass, small tufted } \\
\text { lovegrass, or soft } \\
\text { lovegrass } \\
\end{array}$ & 2 & 2 & 0.13 & 0.5 & 1.0 & 3.51 & 0.18 & 0.40 & 4.09 \\
\hline & & 57 & 1084 & 3.8 & 289.1 & 252.4 & 100.0 & 100.0 & 100.0 & 300.0 \\
\hline
\end{tabular}

Number of individuals $=$ total number per species; Frr = relative frequency; Der = relative fens.; Abr = relative abundance; IVI = Importance Value Index. 
Table 2 - Phytosociological parameters of weeds identified in carpet grass (A. compressus) at CEDETEG/UNICENTRO campus during June 2013. Guarapuava, PR, 2013

\begin{tabular}{|c|c|c|c|c|c|c|c|c|c|c|}
\hline Species & Common name & $\begin{array}{l}\text { No. of } \\
\text { frames }\end{array}$ & \begin{tabular}{|c|} 
No. of \\
individuals
\end{tabular} & Fre & Den & $\mathrm{Abu}$ & Frr & Der & Abr & IVI \\
\hline Hypochoeris brasiliensis & Brazilian cat's ear & 35 & 277 & 0.51 & 16.1 & 7.9 & 17.59 & 18.58 & 17.76 & 53.92 \\
\hline Trifolium repens & $\begin{array}{l}\text { white clover, Dutch } \\
\text { clover, or Ladino } \\
\text { (clover) }\end{array}$ & 48 & 743 & 0.70 & 43.1 & 15.5 & 24.12 & 49.83 & 34.73 & 108.68 \\
\hline Taraxacum officinale & common dandelion & 28 & 105 & 0.41 & 6.0 & 3.7 & 14.07 & 7.04 & 8.41 & 29.53 \\
\hline Hypochaeris radicata & $\begin{array}{l}\text { catsear, flatweed, } \\
\text { cat's-ear, hairy cat's } \\
\text { ear, or false } \\
\text { dandelion }\end{array}$ & 26 & 50 & 0.38 & 2.9 & 1.9 & 13.07 & 3.35 & 4.31 & 20.73 \\
\hline Soliva pterosperma & $\begin{array}{l}\text { field burrweed, } \\
\text { Onehunga-weed, } \\
\text { lawn burrweed, } \\
\text { lawnweed, soliva, } \\
\text { bindi weed, bindii, } \\
\text { or bindi-eye }\end{array}$ & 25 & 122 & 0.36 & 7.0 & 4.8 & 12.56 & 8.18 & 10.95 & 31.69 \\
\hline Bulbo stylis capilaris & $\begin{array}{l}\text { densetuft hairsedge } \\
\text { or threadleaf } \\
\text { beakseed }\end{array}$ & 19 & 52 & 0.28 & 3.0 & 2.7 & 9.55 & 3.49 & 6.14 & 19.18 \\
\hline \multirow[t]{2}{*}{ Indigofera hirsuta } & $\begin{array}{l}\text { Hairy indigo, rough } \\
\text { hairy indigo }\end{array}$ & 18 & 142 & 0.26 & 8.2 & 7.9 & 9.05 & 9.52 & 17.70 & 36.27 \\
\hline & & 199 & 1491 & 2.9 & 86.4 & 44.6 & 100.0 & 100.0 & 100.0 & 300.0 \\
\hline
\end{tabular}

Number of individuals $=$ total number per species; Frr = relative frequency; Der = relative density; Abr = relative abundance; IVI = Importance Value Index.

Uddin et al. (2014), the presence of a weeds community disrupts the lawn uniformity due to the variability in growth habit, color and width of the leaves. Moreover, the presence of weeds interferes with the lawn texture and aesthetic and may cause difficulties in maintaining mowing (Hephner et al., 2012).

In December, the three species that registered the highest relative frequencies were $O$. latifolia, $H$. brasiliensis e $B$. capilaris, represented, respectively, by levels of $18.8 \%$, $14.8 \%$ and $11.9 \%$ (Table 4 ). For the relative density, the biggest highlight of December was obtained by $O$. latifolia (46.8\%) and $T$. repens (20.4\%). According to Grigoletto et al. (2014), genus Oxalis is represented by 27 species of the Brazilian state of Rio Grande do Sul, among them Oxalis subvillosa, a new occurrence in the state, and Oxalis lindneri, in Brazil.

As for the relative abundance, an important phytosociological parameter that shows the species that appear in foci, or even more concentrated in the evaluations, those that stand out as prevailing are S. pterosperma $(16.4 \%)$ and T. repens (14.7\%) in April; T. repens
$(34.7 \%)$ in June; O. corniculata $(28.7 \%)$ and T. repens $(22.9 \%)$ in October; and $O$. latifolia $(22.9 \%)$ and $T$. repens $(21.0 \%)$ in December (Tables 1, 2, 3 and 4).

Although the floristic survey has covered periods in very different climatic conditions, it is important to note that June was characterized by low temperatures and regular rainfall (Figure 1), which may have discouraged the emergence of a greater number of species and families in the period.

The weeds that had the highest importance value index (IVI) were, in descending order: S. pterosperma $(66.5 \%)$, T. repens $(56.1 \%)$, B. capilaris $(33.0 \%)$ and $O$. corniculata $(24.0 \%)$ in April; T. repens (108.7\%) in June; T. repens (61.8\%), O. corniculata (53.2\%), S. pterosperma $(50.6 \%)$ and O. latifolia (27.6\%) in October; and O. latifolia $(88.5 \%)$ and $T$. repens $(50.3 \%)$ in December (Tables 1, 2, 3 and 4). For species $S$. pterosperma and $T$. repens there are no other reports in the national literature about phytosociological surveys on lawn that indicate them as having a high importance value. However, for genus Oxalis, the results obtained 
Table 3 - Phytosociological parameters of weeds identified in carpet grass (A. compressus) at CEDETEG/UNICENTRO campus during October 2013. Guarapuava, PR, 2013

\begin{tabular}{|c|c|c|c|c|c|c|c|c|c|c|}
\hline Species & Common name & $\begin{array}{l}\text { No. of } \\
\text { frames }\end{array}$ & \begin{tabular}{|c|} 
No. of \\
individuals
\end{tabular} & Fre & Den & $\mathrm{Abu}$ & Frr & Der & Abr & IVI \\
\hline Hypochaeris radicata & $\begin{array}{l}\text { catsear, flatweed, cat's- } \\
\text { ear, hairy cat's ear, or } \\
\text { false dandelion }\end{array}$ & 19 & 43 & 0.29 & 2.6 & 2.3 & 8.52 & 1.44 & 1.09 & 11.05 \\
\hline Hypochoeris brasiliensis & Brazilian cat's ear & 21 & 46 & 0.32 & 2.8 & 2.2 & 9.42 & 1.54 & 1.06 & 12.02 \\
\hline Taraxacum officinale & common dandelion & 27 & 68 & 0.42 & 4.2 & 2.5 & 12.11 & 2.28 & 1.22 & 15.60 \\
\hline Indigofera hirsuta & $\begin{array}{l}\text { Hairy indigo, rough } \\
\text { hairy indigo }\end{array}$ & 5 & 17 & 0.08 & 1.1 & 3.4 & 2.24 & 0.57 & 1.64 & 4.45 \\
\hline Oxalis latifolia & $\begin{array}{l}\text { garden pink-sorrel or } \\
\text { broadleaf woodsorrel }\end{array}$ & 11 & 293 & 0.17 & 18.0 & 26.6 & 4.93 & 9.83 & 12.86 & 27.62 \\
\hline Ambrosia artemisiifolia & $\begin{array}{c}\text { common ragweed, } \\
\text { annual ragweed, or low } \\
\text { ragweed }\end{array}$ & 5 & 32 & 0.08 & 1.9 & 6.4 & 2.24 & 1.07 & 3.09 & 6.41 \\
\hline Ageratum conyzoides & $\begin{array}{c}\text { Billygoat-weed, chick } \\
\text { weed, goatweed, } \\
\text { whiteweed }\end{array}$ & 19 & 36 & 0.29 & 2.2 & 1.9 & 8.52 & 1.21 & 0.91 & 10.64 \\
\hline Aeschynomene denticulata & $\begin{array}{c}\text { In Brazilian Portuguese, } \\
\text { angiquinho }\end{array}$ & 1 & 6 & 0.02 & 0.4 & 6.0 & 0.45 & 0.20 & 2.90 & 3.55 \\
\hline Sida rhombifolia & $\begin{array}{c}\text { False mallow, broom } \\
\text { weed, clock plant, or } \\
\text { prickly malvastrum }\end{array}$ & 28 & 108 & 0.43 & 6.6 & 3.8 & 12.56 & 3.62 & 1.86 & 18.04 \\
\hline Richardia brasiliensis & $\begin{array}{c}\text { Tropical Mexican } \\
\text { clover, Brazilian calla- } \\
\text { lily, white-eye, or Brazi } \\
\text { pusley }\end{array}$ & 17 & 48 & 0.26 & 2.9 & 2.8 & 7.62 & 1.61 & 1.36 & 10.60 \\
\hline Centella asiatica & $\begin{array}{l}\text { centella, gotu kola, } \\
\text { Asiatic pennywort, or } \\
\text { Indian pennywort }\end{array}$ & 2 & 21 & 0.03 & 1.3 & 10.5 & 0.90 & 0.70 & 5.07 & 6.67 \\
\hline Solivia pterosperma & Rosette & 32 & 746 & 0.49 & 45.9 & 23.3 & 14.35 & 25.02 & 11.26 & 50.62 \\
\hline Trifolium repens & $\begin{array}{l}\text { white clover, Dutch } \\
\text { clover, or Ladino } \\
\text { (clover) }\end{array}$ & 19 & 904 & 0.29 & 55.6 & 47.6 & 8.52 & 30.32 & 22.97 & 61.81 \\
\hline Synedrellopsis grisebachii & Straggler daisy & 2 & 2 & 0.03 & 0.1 & 1.0 & 0.90 & 0.07 & 0.48 & 1.45 \\
\hline Bulbostylis capillaris & $\begin{array}{c}\text { densetuft hairsedge or } \\
\text { threadleaf beakseed }\end{array}$ & 4 & 13 & 0.06 & 0.8 & 3.2 & 1.79 & 0.44 & 1.57 & 3.80 \\
\hline Setaria geniculata & $\begin{array}{c}\text { marsh bristlegrass, } \\
\text { knotroot bristle-grass, } \\
\text { bristly foxtail, or yellow } \\
\text { bristlegrass }\end{array}$ & 1 & 4 & 0.02 & 0.2 & 4.0 & 0.45 & 0.13 & 1.93 & 2.51 \\
\hline Oxalis corniculata & $\begin{array}{c}\text { creeping woodsorrel, } \\
\text { procumbent yellow- } \\
\text { sorrel, or sleeping } \\
\text { beauty }\end{array}$ & 10 & 595 & 0.15 & 36.6 & 59.5 & 4.48 & 19.95 & 28.73 & 53.16 \\
\hline & & 223 & 2982 & 3.43 & 183.5 & 207.1 & 100.0 & 100.0 & 100.0 & 300.0 \\
\hline
\end{tabular}

Number of individuals $=$ total number per species; Frr = relative frequency Der = relative density; Abr = relative abundance; IVI = Importance Value Index.

corroborate those described by Maciel et al. (2010b) in dwarf eelgrass or Japanese eelgrass (Z. japonica), in which the highest Importance Value Index (IVI) has occurred for O. corniculata in March (26.4\%), July (69.4\%) and October $(65.4 \%)$, as well as for O. latifolia (49.2\%) only in July.

The similarity index (SI) of the species found in the periods analyzed showed an intermediate similarity in weed flora infesting carpet grass in the comparison from April to October, from April to December, from June to October and from June to December, as well as a high similarity for the months from October to December (Table 5). For a comparison from April to June, there was a low similarity in the weed flora, where the SI was only $19.4 \%$, because only three species were common for those months. According to Matteucci and 
Colma (1982), values above $25 \%$ indicate a similarity between the factors compared by this index. However, it is important to note that the similarity index (SI) involves only the absence or presence of the species in the area, not considering information such as density, biomass and distribution (Kuva et al., 2007).

Thus, the low similarity of the infestation just for comparison between April to June again can be explained by the greater distinction between the climatic conditions of temperature and rainfall that occurred in those periods (Figure 1). It is important to note that the lawn management could hardly influence the dynamics of germination and development of the weed population, since mowing maintenance practices, as well as the absence of fertilization and irrigation, were procedures equally adopted in every month of 2013.

In the phytosociological survey of weeds in lawn of carpet grass (A. compressus) at CEDETEG/UNICENTRO campus located in the Brazilian municipality of Guarapuava, PR, species Trifolium repens (Fabaceae), Soliva pterosperma (Asteraceae) and Oxalis corniculata (Oxalidaceae) were identified as the most important from April to December 2013. Moreover, it was observed that the similarity

Table 4 - Phytosociological parameters of weeds identified in carpet grass (A. compressus) at CEDETEG/UNICENTRO campus during December 2013. Guarapuava, PR, 2013

\begin{tabular}{|c|c|c|c|c|c|c|c|c|c|c|}
\hline Species & Common name & $\begin{array}{l}\text { No. of } \\
\text { frames }\end{array}$ & $\begin{array}{c}\text { No. of } \\
\text { individuals }\end{array}$ & Fre & Den & $\mathrm{Abu}$ & Frr & Der & Abr & IVI \\
\hline Kyllinga brevifolia & $\begin{array}{l}\text { shortleaf spikesedge, } \\
\text { green kyllinga, or } \\
\text { perennial greenhead } \\
\text { sedge }\end{array}$ & 4 & 9 & 0.13 & 1.1 & 2.2 & 3.96 & 0.71 & 1.64 & 6.31 \\
\hline Hypoxis decumbens & $\begin{array}{c}\text { In Brazilian Portuguese } \\
\text { mariço-bravo }\end{array}$ & 4 & 6 & 0.13 & 0.7 & 1.5 & 3.96 & 0.47 & 1.10 & 5.53 \\
\hline Oxalis latifolia & $\begin{array}{l}\text { garden pink-sorrel or } \\
\text { broadleaf woodsorrel }\end{array}$ & 19 & 595 & 0.59 & 74.4 & 31.3 & 18.81 & 46.81 & 22.87 & 88.50 \\
\hline Trifolium repens & $\begin{array}{l}\text { white clover, Dutch } \\
\text { clover, or Ladino } \\
\text { (clover) }\end{array}$ & 9 & 259 & 0.28 & 32.4 & 28.8 & 8.91 & 20.38 & 21.02 & 50.31 \\
\hline Indigofera hirsuta & $\begin{array}{l}\text { Hairy indigo, rough } \\
\text { hairy indigo }\end{array}$ & 5 & 89 & 0.16 & 11.1 & 17.8 & 4.95 & 7.00 & 13.00 & 24.95 \\
\hline Bulbostylis capillaris & $\begin{array}{c}\text { densetuft hairsedge or } \\
\text { threadleaf beakseed }\end{array}$ & 12 & 38 & 0.38 & 4.7 & 3.2 & 11.88 & 2.99 & 2.31 & 17.18 \\
\hline Taraxacum officinale & common dandelion & 6 & 12 & 0.19 & 1.5 & 2.0 & 5.94 & 0.94 & 1.46 & 8.35 \\
\hline Dichondra repens & $\begin{array}{c}\text { In Brazilian Portuguese } \\
\text { dinheiro-em-penca }\end{array}$ & 5 & 69 & 0.16 & 8.6 & 13.8 & 4.95 & 5.43 & 10.08 & 20.46 \\
\hline Soliva pterosperma & Rosette & 3 & 23 & 0.09 & 2.8 & 7.7 & 2.97 & 1.81 & 5.60 & 10.38 \\
\hline Hypochoeris brasiliensis & Brazilian cat's ear & 15 & 45 & 0.47 & 5.6 & 3.0 & 14.85 & 3.54 & 2.19 & 20.58 \\
\hline Synedrellopsis grisebachii & Straggler daisy & 5 & 57 & 0.16 & 7.1 & 11.4 & 4.95 & 4.48 & 8.33 & 17.76 \\
\hline Hypochaeris radicata & $\begin{array}{l}\text { catsear, flatweed, cat's- } \\
\text { ear, hairy cat's ear, or } \\
\text { false dandelion }\end{array}$ & 4 & 9 & 0.13 & 1.1 & 2.2 & 3.96 & 0.71 & 1.64 & 6.31 \\
\hline Chaptalia integerrima & $\begin{array}{c}\text { In Brazilian Portuguese } \\
\text { paraquedinha }\end{array}$ & 5 & 23 & 0.16 & 2.9 & 4.6 & 4.95 & 1.81 & 3.36 & 10.12 \\
\hline Ageratum conyzoides & $\begin{array}{l}\text { Billygoat-weed, chick } \\
\text { weed, goatweed, } \\
\text { whiteweed }\end{array}$ & 5 & 37 & 0.16 & 4.6 & 7.4 & 4.95 & 2.91 & 5.40 & 13.27 \\
\hline \multicolumn{2}{|r|}{ 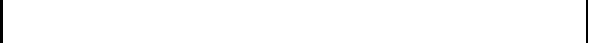 } & 101 & 1271 & 3.2 & 158.9 & 136.9 & 100.0 & 100.0 & 100.0 & 300.0 \\
\hline
\end{tabular}

Number of individuals = total number per species; Frr = relative frequency; Der = relative density; Abr = relative abundance; IVI = Importance Value Index. 
Table 5 - Evaluation of floristic similarity (SI\%) of weeds identified in carpet grass (A. compressus) at CEDETEG/ UNICENTRO campus between April and December 2013. Guarapuava, PR, 2013

\begin{tabular}{|l|c|c|c|c|}
\hline \multirow{2}{*}{ Comparison } & \multicolumn{4}{|c|}{ Similarity index (SI\%) } \\
\cline { 2 - 5 } & April & June & October & December \\
\hline April & $*_{-} *$ & 19.4 & 48.8 & 36.8 \\
\hline June & $*_{-} *$ & $*_{-} *$ & 58.3 & 47.6 \\
\hline October & $*_{-} *$ & $*_{-} *$ & $*_{-} *$ & 71.0 \\
\hline December & $*_{-} *$ & $*_{-} *$ & $*_{-} *$ & $*_{-} *$ \\
\hline
\end{tabular}

of the weed community between April and December 2013 was classified as intermediate to high, except for the comparison between April and June, which was characterized as low.

\section{ACKNOWLEDGEMENT}

The authors are grateful to Capes/ Fundação Araucária (Coordenação de Aperfeiçoamento de Pessoal de Nivel Superior/ Fundação Araucária) for granting the scholarship.

\section{REFERENCES}

Angiosperm Phylogeny Group - APG II. An update of the Angiosperm Phylogeny Group classification for the orders and families of flowering plants: APG II. Bot J Linn Soc. 2003; 141:399-436.

Busey P. Cultural management of weeds in turfgrass. Crop Sci. 2003;43:1899-911.

Concenço G. et al. Phytosociological surveys: tools for weed science? Planta Daninha. 2013;31:469-82.

Deuber R. Manejo de plantas daninhas em áreas não agrícolas. In: Ciência das plantas infestantes: manejo. Campinas: Edição do autor, 1997. p.273-5.

Empresa Brasileira de Pesquisa Agropecuária - Embrapa. Sistema Brasileiro de Classificação de Solos. $3^{\text {a }}$ ed. Brasília: 2013. 353 p.

Freitas F.C.L. et al. Eficiência do triclopyr no controle de plantas daninhas em gramado (Paspalum notatum). Planta Daninha. 2003;21:159-64.

Grombone-Guaratini M.T., Rodrigues R.R. Seed bank and seed rain in a seasonal semi-deciduous forest in south-eastern Brazil. J Trop Ecol. 2002;18:759-74.
Grigoletto D. O gênero Oxalis L. (Oxalidaceae) no Rio Grande do Sul, Brasil. Ci Natura. 2014;36:594-612.

Hephner A.J. et al. Sequential postemergence applications for the control of khaki weed in bermudagrass turf. HortScience. 2012;47:434-36.

Kissmann K.G., Groth D. Plantas infestantes e nocivas. $2^{\mathrm{a}}$ ed. São Paulo: 1997. Tomo I. 824p.

Kissmann K.G., Groth D. Plantas infestantes e nocivas. $2^{\text {a }}$ ed. São Paulo: 1999. Tomo II. 978p.

Kissmann K.G., Groth D. Plantas infestantes e Nocivas. $2^{\mathrm{a}}$ ed. São Paulo: 2000. Tomo III. 722p.

Kojoroski-Silva C.M. et al. Desenvolvimento morfológico das gramas esmeralda, são carlos e tifton 419. Ci Agrotecnol. 2011;35:471-7.

Köppen W. Climatologia: com um estudio de los climas de la tierra. México: Fondo de Cultura Econômica, 1948.

Kuva M.A. et al. Fitossociologia de comunidades de plantas daninhas em agroecossistema cana-crua. Planta Daninha. 2007;25:501-11.

Lorenzi H., Souza H.M. Plantas ornamentais do Brasil: arbustivas, herbáceas e trepadeiras. $3^{\mathrm{a}}$ ed. Nova Odessa: 200. $558 \mathrm{p}$.

Lorenzi H. Plantas daninhas do Brasil: terrestres, aquáticas, parasitas e tóxicas. $4^{\mathrm{a}}$ ed. Nova Odessa: 2008. $640 \mathrm{p}$.

Maciel C.D.G. et al. Composição florística da comunidade infestante em gramados de Paspalum notatum no município de Assis, SP. Planta Daninha. 2008;26:57-64.

Maciel C.D.G. et al. Monitoramento de plantas daninhas em gramados de grama-batatais (Paspalum notatum Flügge) no Município de Paraguaçu Paulista, SP. Rev Bras Hortic Ornam. 2010a;16:85-94.

Maciel C.D.G., Souza J.I., Hama J.T. Levantamento fitossociológico de plantas daninhas em jardins residenciais com grama esmeralda em Ourinhos - SP. Global Sci Technol. 2010b;3:39-48.

Matteucci S.D., Colma A. Metodología para el estudio de la vegetatión. Washington: OEA; 1982.

Müeller-Dombois, D., Ellenberg, H. Aims and methods of vegetation ecology. New York: J. Wiley, 1974. 547p.

Planta Daninha, Viçosa-MG, v. 34, n. 4, p. 691-700, 2016 
Nordi J.C., Landgraf P.R.C. Composição florística e fitossociologia da comunidade composição infestante em gramado de Paspalum notatum Flügge no laboratório de botânica da Universidade de Taubaté, SP. Rev Bioci. 2009;15:106-14.

Oliveira A.R., Freitas S.P. Levantamento fitossociológico de plantas daninhas em áreas de produção de cana-de-açúcar. Planta Daninha. 2008;26:33-46.

Oliveira C.A.V.M. Fitossociologia da comunidade infestante de gramados de grama-batatais (Paspalum notatum Flügge) em praças de Jaboticabal, SP [dissertação]. Jaboticabal: Universidade Estadual Paulista "Júlio de Mesquita Filho," 2011.
Silva A.M.A., Coelho I.D., Medeiros P.R. Levantamento florístico das plantas daninhas em um parque público de Campina Grande, Paraíba, Brasil. Rev Biotemas. 2008;21:714.

Souza V.C., Lorenzi H. Botânica sistemática: guia ilustrado para identificação das famílias de angiospermas da flora brasileira, baseado em APG II. Nova Odessa: Plantarum, 2005.

Uddin M.K. et al. Seawater: An alternative grassy weed control method for post emergence herbicides in tropical turfgrass. Pakistan J Agric Sci. 2014;51:153-60.

Vermeij G.J. An agenda for invasion biology. Biol Conserv. 1996;78:3-9. 